\title{
High-level $\beta$-globin expression and preferred intragenic integration after lentiviral transduction of human cord blood stem cells
}

\author{
Suzan Imren, ${ }^{1}$ Mary E. Fabry, ${ }^{2}$ Karen A. Westerman, ${ }^{3}$ Robert Pawliuk, ${ }^{3}$ Patrick Tang, ${ }^{1}$ \\ Patricia M. Rosten, ${ }^{1}$ Ronald L. Nagel, ${ }^{2,4}$ Philippe Leboulch, ${ }^{3,5}$ Connie J. Eaves, ${ }^{1,6}$ \\ and R. Keith Humphries ${ }^{1,7}$
}

\begin{abstract}
'Terry Fox Laboratory, British Columbia Cancer Agency, Vancouver, British Columbia, Canada. ${ }^{2}$ Department of Medicine (Division of Hematology) and Physiology and Biophysics, Albert Einstein College of Medicine, Bronx, New York, USA. ${ }^{3}$ Genetics Division, Department of Medicine and Harvard Medical School, Brigham and Women's Hospital, Harvard New Research Building, Boston, Massachusetts, USA. ${ }^{4}$ Department of Physiology and Biophysics, Albert Einstein College of Medicine, Bronx, New York, USA. ${ }^{5}$ Department of Medicine and Harvard Medical School, Brigham and Women's Hospital, Boston, Massachusetts, USA. ${ }^{6}$ Departments of Medical Genetics and ${ }^{7}$ Medicine, University of British Columbia, Vancouver, British Columbia, Canada.
\end{abstract}

\begin{abstract}
Transplantation of genetically corrected autologous hematopoietic stem cells is an attractive approach for the cure of sickle-cell disease and $\beta$-thalassemia. Here, we infected human cord blood cells with a self-inactivating lentiviral vector encoding an anti-sickling $\beta^{\mathrm{A}-\mathrm{T} 87 \mathrm{Q}}$-globin transgene and analyzed the transduced progeny produced over a 6-month period after transplantation of the infected cells directly into sublethally irradiated NOD/LtSz-scid/scid mice. Approximately half of the human erythroid and myeloid progenitors regenerated in the mice containing the transgene, and erythroid cells derived in vitro from these in vivo-regenerated cells produced high levels of $\beta^{\mathrm{A}-\mathrm{T} 8 \mathrm{Q}}$-globin protein. Linker-mediated PCR analysis identified multiple transgenepositive clones in all mice analyzed with $2.1 \pm 0.1$ integrated proviral copies per cell. Genomic sequencing of vector-containing fragments showed that $86 \%$ of the proviral inserts had occurred within genes, including several genes implicated in human leukemia. These findings indicate effective transduction of very primitive human cord blood cells with a candidate therapeutic lentiviral vector resulting in the long-term and robust, erythroidspecific production of therapeutically relevant levels of $\beta$-globin protein. However, the frequency of proviral integration within genes that regulate hematopoiesis points to a need for additional safety modifications.
\end{abstract}

\section{Introduction}

Sickle-cell disease (SCD) and $\beta$-thalassemia are life-threatening inherited disorders of red cell malfunction of major worldwide importance. Both are caused by alterations to the $\beta$-globin gene, which is required for normal hemoglobin production in adults. Currently, allogeneic bone marrow transplantation is the only therapy that can produce permanent cures in patients with these disorders $(1,2)$. However, this approach is limited by lack of suitably matched donors and the significant morbidity and mortality associated with the treatment.

Transplantation of genetically corrected autologous hematopoietic stem cells (HSCs) could circumvent both of these drawbacks, and the development of this approach has therefore been a goal of basic and preclinical studies for many years. These investigations have led to a number of important advances including the identification of the locus control region (LCR) of the $\beta$-globin gene cluster (3-6) and the demonstration of the importance of specific elements within

Nonstandard abbreviations used: BFU-E, burst forming unit-erythroid; Epo, erythropoietin; FL, Flt-3 ligand; HSC, hematopoietic stem cell; LCR, locus control region; LM-PCR, linker-mediated PCR; LTR, long terminal repeat; NOD/SCID, NOD/ LtSz-scid/scid; NOD/SCID-nu/nu, NOD/LtSz-scid/scid nu/nu; SCD, sickle-cell disease; SF, Steel factor; TAE, Tris-acetate EDTA; Tpo, thrombopoietin.

Conflict of interest: C.J. Eaves and R.K. Humphries are paid consultants of StemCell Technologies Inc., suppliers of some of the culture reagents used in this study; R. Pawliuk, K.A. Westerman, and P. Leboulch are officers of Genetix Pharmaceutical Inc.

Citation for this article: J. Clin. Invest. 114:953-962 (2004)

doi:10.1172/JCI200421838 the LCR in promoting high-level, erythroid-specific, and positionindependent expression of the $\beta$-globin gene (7-10).

Efforts to incorporate these LCR elements into oncoretroviral vectors have yielded some promising results in both mouse (11-14) and human targets $(15,16)$. However, the generation of high titers of intact oncoretroviral vectors encoding sufficient portions of the LCR to achieve maximal $\beta$-globin transgene expression in primary cells has proven difficult $(11,15-20)$. In addition, obtaining clinically relevant yields of transduced HSCs remains a challenge with these vectors. This is due to the decline in HSC activity that occurs during the several days of growth factor stimulation in culture required for their efficient transduction (21-23).

Lentiviral vectors can also infect primitive primary human hematopoietic cells at high efficiencies (50\% and more) but with much shorter in vitro-transduction protocols (24-32). Also, the rev-responsive element in the vector facilitates the export of unspliced transcripts into the cytoplasm, thereby promoting higher protein expression (33). Lentiviral vectors may also be less prone to silencing $(34,35)$. Thus, a number of groups have been evaluating the potential of lentiviral vectors as potentially superior vehicles for globin gene transfer applications (36-41). We have focused on the development of a lentiviral vector containing an anti-sickling human $\beta^{\mathrm{A}-\mathrm{T} 87 \mathrm{Q}}$-globin expression cassette that includes a 2.7-kb region of the LCR (comprising the DNase I-hypersensitive 2,3 , and 4 elements) $(37,38)$. Evaluations of the therapeutic utility of this vector in murine models of SCD (37) and $\beta$-thalassemia (38) have, in both cases, demonstrated pancellular expression of 

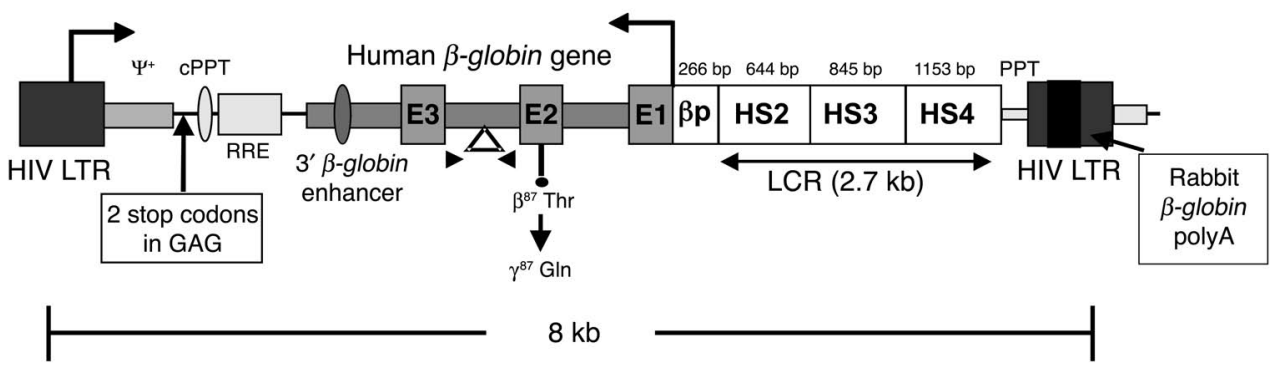

$8 \mathrm{~kb}$

Figure 1

Schematic diagram of the self-inactivating $\beta^{A-T 87 Q}$-globin lentiviral vector used in this study. Features include the HIV LTR; the packaging signal $\left(\psi^{+}\right)$; the central polypurine tract (cPPT); the rev-responsive element (RRE); the $\beta$-globin promoter, from SnaBI to the cap site ( $\left.\beta \mathrm{p}\right)$; the $3^{\prime} \beta$-globin enhancer (to the downstream Avrll site); the 372-bp IVS2 deletion (indicated by the triangle); the $\beta^{\text {A-T87Q }}$ mutation (ACA Thr [ $\beta^{87}$ Thr] to CAG GIn [ $\left.\gamma^{87} \mathrm{Gln}\right]$ ); and the DNase I-hypersensitive sites, Smal to Xbal (HS2), Sacl to Pvull (HS3), and Stul to Spel (HS4) of the $\beta$-globin LCR; 2 stop codons in the $\psi^{+}$packaging signal; the 400 -bp deletion in U3 of the right-hand HIV LTR; and the rabbit $\beta$-globin polyA signal. The locations of the

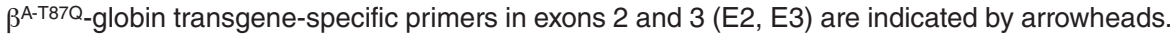

the transduced $\beta$-globin gene with nearly complete correction of the disease phenotype in recipients of transduced HSCs containing an average of 3 proviral integrations per cell.

The present study was undertaken to test the ability of this vector to transduce HSCs of human origin and to measure the level of $\beta$-globin transgene expression achieved in their erythroid progeny. The results show efficient transduction of HSCs in normal cord blood as detected by their ability to repopulate sublethally irradiated immunodeficient (NOD/LtSz-scid/scid, or NOD/SCID) mice for at least 6 months. In addition, production of clinically relevant levels of $\beta$-globin protein in the erythroid progeny of the transduced HSCs has been demonstrated. Additional evidence of the preferred intragenic integration of such vectors has also been obtained including insertions into genes implicated in human leukemia.

\section{Results}

Efficient lentiviral transfer of a $\beta^{A-T 87 Q}$-globin transgene into primitive buman cord blood cells. As an initial test of the ability of our safety-

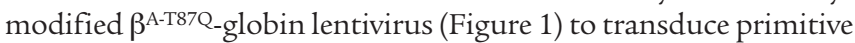
human hematopoietic cells, the proportion of vector-containing hematopoietic colonies was determined on cells plated immedi-

\section{Figure 2}

Assessment of $16 \mathrm{NOD} / \mathrm{SCID}$ mice and 3 NOD/SCID-nu/nu mice

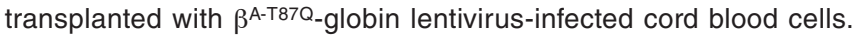
(A) Time course studies of the total number of human hematopoietic (CD45/71+) cells generated in two representative experiments. Values are the mean \pm SEM for 8 mice in experiment 1 (filled squares) and 11 mice in experiment 2 (filled circles). Of all cells present in the marrow in experiment 1, 20 weeks after transplant, $4 \% \pm 2 \%$ were B-lymphoid $\left(C D 19 / 20^{+}\right)$cells and $0.7 \% \pm 0.4 \%$ were mature granulopoietic $\left(C D 15^{+}\right)$cells; of all cells present in the marrow in experiment 2,16 weeks after transplant, $63 \% \pm 4 \%$ were B-lymphoid cells and $7 \% \pm 1 \%$ were mature granulopoietic cells. (B) PCR analysis to detect proviruspositive hematopoietic colonies produced by human CFCs isolated from the marrow of individual mice $(n=18)$ at different time points after transplant in a total of five experiments. Values determined at 3 weeks after transplant are not connected to the values determined at later time points because the cells present at these two different times are thought to be derived from different types of repopulating cells (43). The overall proportion of colonies with the $\beta^{A-T 87 Q}$-globin transgene in all 17 recipients analyzed $11-24$ weeks after transplant was $45 \% \pm 6 \%$ (range 12\%-91\%). ately after a 16-hour exposure of a CD34+ cell-enriched cord blood cell suspension to virus following a prior 48-hour period of stimulation in vitro with the following growth factors alone: Flt-3 ligand (FL), Steel factor (SF), thrombopoietin (Tpo), and hyper-IL-6 (hIL-6). PCR analysis of individual colonies (both granulopoietic and erythroid) using primer pairs specific for the $\beta^{\mathrm{A}-\mathrm{T} 87 \mathrm{Q}-g l o b i n}$ transgene and for GAPDH showed that the DNA from 15 of 40 $\mathrm{GAPDH}^{+}$colonies analyzed (38\%) also contained the $\beta^{\mathrm{A}-\mathrm{T} 87 \mathrm{Q}}$-globin transgene. To determine the efficiency of transducing more primitive cells with multiple-lineage in vivo-repopulating ability, $26 \mathrm{NOD} / \mathrm{SCID}$ and $3 \mathrm{NOD} / \mathrm{LtSz}$-scid/scid nu/nu (NOD/SCID$\mathrm{nu} / \mathrm{nu}$ ) mice were transplanted with infected cord blood cells. In these experiments, $\mathrm{CD}_{3} 4^{+}$cell-enriched suspensions $(n=4$; including experiments 1 and 2 ) or $\mathrm{CD}^{2} 4^{+} \mathrm{CD} 38^{-}$cells isolated by FACS $(n=1)$ were first stimulated with growth factors for 18 hours, exposed to

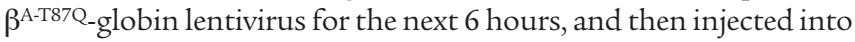
the mice. FACS analysis of serial femoral marrow aspirates obtained from these mice confirmed that the transplants had regenerated persistent populations of hematopoietic $\left(\mathrm{CD} 45 / 71^{+}\right)$cells. Figure $2 \mathrm{~A}$ shows representative data from two experiments. The variation in the number of human cells regenerated in these two experiments
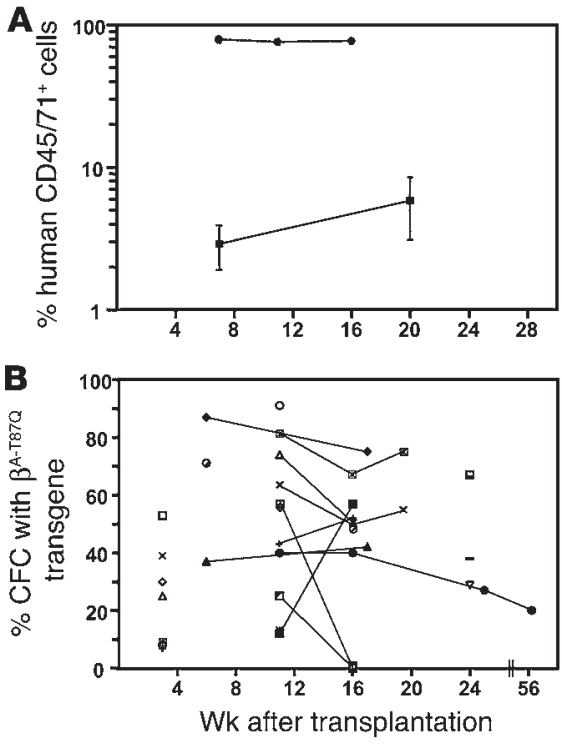
A

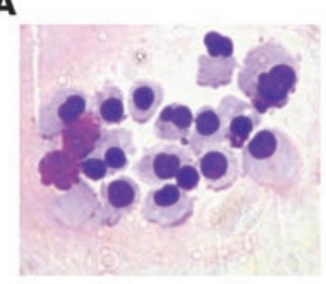

D

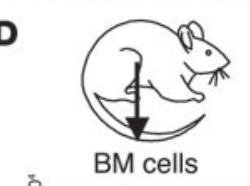

B

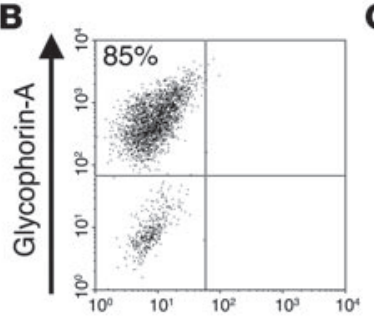

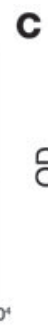

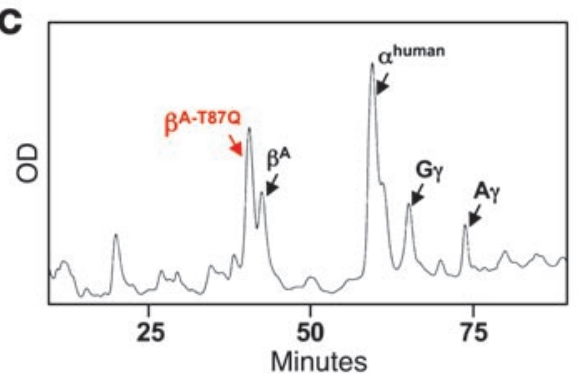

E

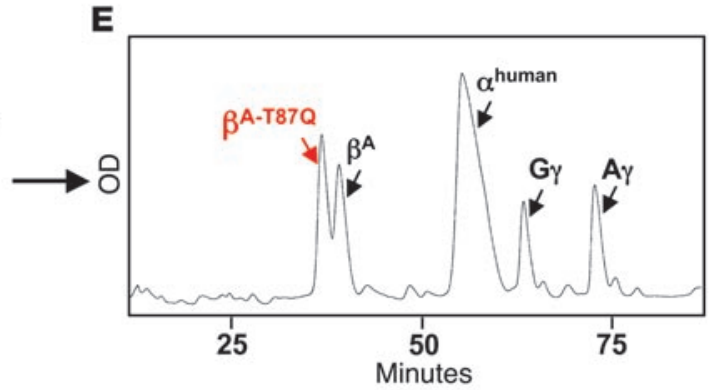

$\mathbf{F}$

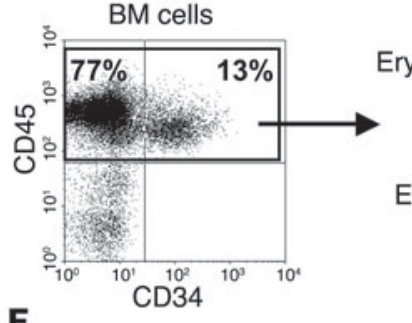

Erythroid suspension cultures

Erythroid colonies
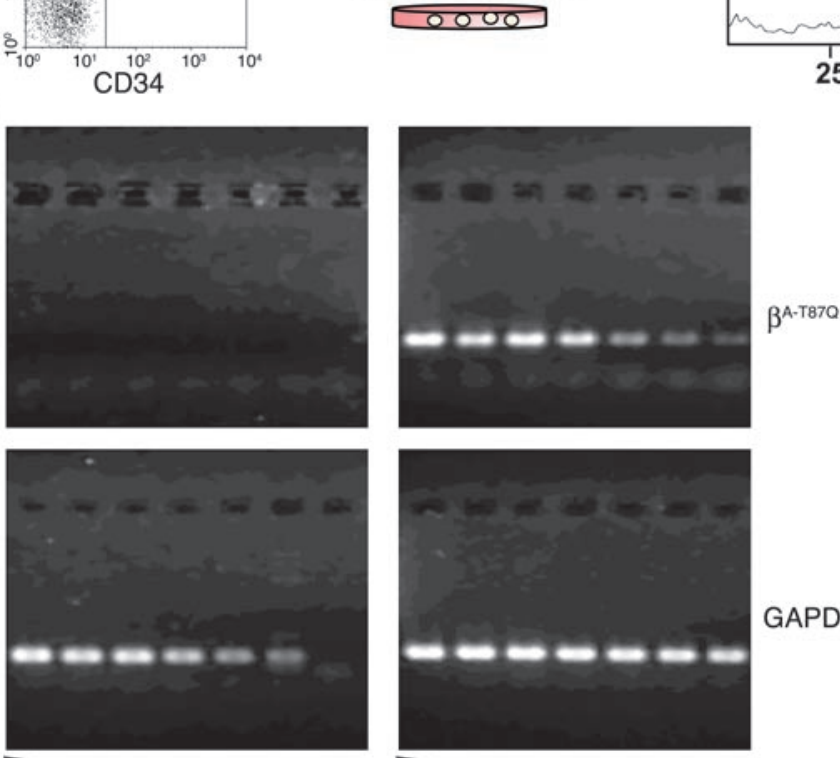

GAPDH

\section{Figure 3}

Lineage-specific expression of human $\beta^{A-T 87 Q}$-globin protein in human erythroid cells generated in vitro. (A) Photomicrograph of Wright-Giemsastained slide preparation of cells from erythroid suspension cultures initiated 14 days previously with cells obtained immediately after exposure to lentivirus. (B) FACS analysis of the cells shown in A after staining with antibodies specific to human glycophorin-A. (C) Representative HPLC profile of a cell lysate obtained from a 14-day culture of cord blood cells set up immediately after infection. Peaks representing differently eluting $\beta$-globin proteins are indicated. (D) Isolation by FACS of human CD45/71+ cells from bone marrow (BM) aspirates of transplanted mice to initiate CFC or suspension cultures that support terminal human erythroid cell differentiation. (E) Representative HPLC profile of a cell lysate from a 14-day suspension culture of human erythroid cells initiated with cells obtained from a mouse that received a transplant of transduced cord blood cells 11 weeks previously. (F) RT-PCR analysis of RNA extracted from cells shown in A (right panels) and human CD19/20+ B-lymphoid cells isolated by FACS (left panels) from a marrow sample of a repopulated mouse 19 weeks after transplant. The $\beta^{A-T 87 Q}$-globin transcript was detected in erythroblasts even when diluted 32 times (top right panel), whereas no signal was seen in the extract of B-lymphoid cells (top left panel). Triangles indicate decreasing concentration.

is probably due to differences in the number of $\mathrm{CD} 34^{+}$cells transplanted per mouse $\left(1.65 \times 10^{5}\right.$ versus $\left.4.0 \times 10^{5}\right)$ and also to differences in frequency of repopulating cells in the two pools of cord blood used. As expected (42), by 16-20 weeks after the transplant, the regenerated human cells were predominantly B-lymphoid $\left(\mathrm{CD} 19 / 20^{+}\right)$, with a minority of mature granulopoietic $\left(\mathrm{CD} 15^{+}\right)$elements, in almost all $(15 / 19)$ of the mice. Overall, from five experiments, 19 of 29 recipients were monitored for a minimum of 18 and up to 24 weeks, and $75 \%$ of these maintained significant levels of human lymphoid and myeloid cells $(35 \% \pm 9 \%$ total human cells; $23 \% \pm 6 \%$ human B-lymphoid cells, and $7 \% \pm 3 \%$ mature human granulopoietic cells).

Figure $2 \mathrm{~B}$ shows the results of the PCR analysis of the regenerated human CFCs isolated from 15 NOD/SCID and 3 NOD/SCID$n u / n u$ mice at different time points after the transplant (5-40 colonies per mouse per time point indicated). In all but 1 of the 15 


\begin{tabular}{|c|c|c|c|c|}
\hline \multirow[b]{2}{*}{$\begin{array}{l}\text { Wk after } \\
\text { transplant }\end{array}$} & \multicolumn{2}{|c|}{$\% \beta^{\text {A-T870 }} \% \% \beta^{\text {A-T87Q }}+\% \beta^{A}$} & \multicolumn{2}{|c|}{$\% \beta^{\text {A-T870 } / \% \beta \text {-like }}$} \\
\hline & Ery susp cult & BFU-E & Ery susp cult & BFU-E \\
\hline 8 & 34 & 55 & 12 & 35 \\
\hline 11 & 54 & & 33 & \\
\hline 11 & 47 & & 31 & \\
\hline 11 & 46 & & 28 & \\
\hline 11 & 21 & & 13 & \\
\hline 11 & 14 & & 7 & \\
\hline 11 & ND & 38 & ND & 25 \\
\hline 16 & 33 & 41 & 17 & 18 \\
\hline 16 & 29 & & 18 & \\
\hline 24 & 10 & 14 & 6 & 10 \\
\hline 24 & 59 & & 29 & \\
\hline Mean & $35 \pm 5$ & $37 \pm 9$ & $19 \pm 4$ & $22 \pm 5$ \\
\hline
\end{tabular}

A total of 1-10 pooled BFU-E-derived colonies per sample was used. Ery susp cult, erythroid suspension culture; ND, not done.

positive NOD/SCID mice evaluated between 3 and 6 months after the transplant and also in the single positive NOD/SCID-nu/nu recipient followed for evaluation until 13 months after transplant, more than $20 \%$ of the CFCs were found to contain the transgene. In 2 mice, as many as $80-90 \%$ of the regenerated human CFCs were positive. Based on the data for all of the CFCs analyzed (obtained at least 11 weeks after the transplant from 17 mice in five experiments), the overall average transduction efficiency of long-term NOD/SCID mouse-repopulating cells was $45 \%$.

High levels of $\beta^{A-T 870}$-globin protein are produced in the erythroid progeny of transduced human cord blood cells. To investigate the levels of $\beta^{\mathrm{A}-\mathrm{T} 87 \mathrm{Q}}$ globin protein produced by erythroid cells derived from transduced human cord blood cells, we transferred aliquots of cord blood cells immediately after virus exposure to culture conditions designed to promote erythroblast generation and differentiation over a period of 14 days (see Methods). In the two such experiments performed, more than $85 \%$ of the cells at the time of harvest had phenotypic features of maturing glycophorin- $\mathrm{A}^{+}$erythroblasts (Figure 3, A and B). HPLC analysis of lysates of these cells showed that $\beta^{\text {A-T87Q-globin }}$ protein composed $48 \%$ and $59 \%$ of all $\beta$-globin chains (and $24 \%$ and $41 \%$ of all $\beta$-like globin chains) in the two experiments (Figure $3 \mathrm{C}$ ).

The ability of transduced HSCs to generate erythroid progeny that would also produce this level of $\beta^{\mathrm{A}-\mathrm{T} 87 \mathrm{Q}}$-globin protein was then investigated. Direct assessment of in vivo-generated human erythroblasts is, unfortunately, not possible in NOD/SCID mice repopulated with human hematopoietic cells because of the failure of these hosts to support terminal human erythropoiesis beyond 3-4 weeks after irradiation (43). Therefore, we used the FACS to isolate the human $\left(\mathrm{CD} 45 / 71^{+}\right)$cells present in marrow samples obtained from engrafted mice and then stimulated these to differentiate into erythroid cells in culture, either in CFC assays or in suspension cultures (Figure 3D). HPLC analysis of lysates from the cells harvested from the suspension cultures showed $\beta^{\mathrm{A}-\mathrm{T} 87 \mathrm{Q}}$-globin protein to represent $35 \%$ of all $\beta$-globin chains and $19 \%$ of all $\beta$-like globin chains, with values as high as $59 \%$ and $31 \%$, respectively (Table 1). Figure 3E shows a representative HPLC profile resulting from a culture initiated with cells present in a mouse receiving a transplant of transduced cord blood cells 11 weeks before. Similar levels of $\beta^{\text {A-T87Q-globin protein }(37 \%)}$ were also detected in lysates of single or 5-10 pooled erythroid colonies produced from regenerated burst forming unit-erythroids (BFU-Es; Table 1).

RT-PCR analysis of RNA from erythroblasts generated in vitro from transduced cord blood cells confirmed the presence of $\beta^{A-T 87 Q}$-globin transcripts in these cells. A strong signal could be detected when the cDNA prepared from these extracts was diluted up to 32 times (Figure 3F, top right panel). In contrast, similar analysis of RNA extracts prepared from human B-lymphoid cells isolated by FACS from 2 mice repopulated with transduced

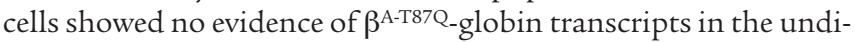
luted cDNA (Figure 3F, top left panel). This demonstrates the erythroid specificity of expression of the $\beta^{\mathrm{A}-\mathrm{T} 87 \mathrm{Q}}$-globin transgene achieved in human cells transduced with this vector, as previously observed in murine cells (37).

Polyclonal reconstitution of NOD/SCID mice transplanted with $\beta^{A-T 87 Q}$-globin lentiviral vector-infected cord blood cells. To investigate the number and stability of transduced clones obtained in NOD/SCID mice transplanted with $\beta^{\mathrm{A}-\mathrm{T} 87 \mathrm{Q}-\text { globin lentiviral }}$ vector-infected cord blood cells, and to obtain an estimate of the number of copies present in each repopulating cell, we used "bubble" linker-mediated PCR (LM-PCR). A total of 121 human CFC-derived colonies from 11 mice that had been confirmed to contain the $\beta^{\mathrm{A}-\mathrm{T} 87 \mathrm{Q}}$-globin transgene were analyzed individually. These included CFCs from 2 mice that were assessed at different time points after receiving transplants. Agarose gel electrophoresis of the LM-PCR products showed that the cells in each colony contained, on average ( \pm SEM), $2.1 \pm 0.1$ copies of provirus. Multiple unique integration patterns were frequently detected in the different CFCs harvested from a single mouse, indicating the presence of multiple clones transduced by the $\beta^{A-T 87 Q}$-globin lentivirus contributing to the regenerated human cell population present (Figure 4, A-C). Analysis of colonies generated from sequential marrow aspirates indicated dynamic changes in clonal prevalence during the first 6 months after the transplant in both mice followed in this way. Representative data from one of these mice is shown in Figure 4, D and E.

Preferential intragenic integration of $\beta^{A-T 87 Q}$-globin lentiviral vector into buman HSCs. The products of the LM-PCR include genomic sequences flanking the integrated provirus, thus allowing the site of proviral integration to be ascertained by DNA sequencing. Using this approach, we analyzed the sequences of 48 gel-purified fragments that contained the expected vector-related long terminal repeat (LTR) sequence linked to a flanking genomic sequence. Of these 48 fragments, 35 were unique and were obtained from 33 individual colonies generated in vitro from human CFCs produced in the mice. Of 48 fragments, 13 (27\%) were repeats; that is, the same sequence was observed in at least 2 colonies generated from the same mouse. For 7 of the 35 inserts (20\%), no match was found in the human genome database. Of the remaining 28 inserts, 24 mapped within identified genes $(86 \%)$ and 4 were repetitive elements that could not be mapped. The chromosomal distribution and names of the mapped genes are shown in Figure 5 and in Table 2, respectively. Notably, several integrations occurred in known oncogenes (e.g., MLL and NUP214, both implicated in acute myeloid leukemias), genes involved in signal transduction pathways (e.g., SCAP2), or genes with tumor suppressor activity (e.g., CGBP). Interestingly, the majority of intragenic integration events occurred in introns ( $21 / 24$ or $88 \%)$. 
A

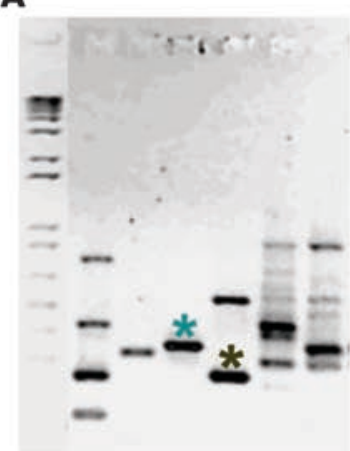

D

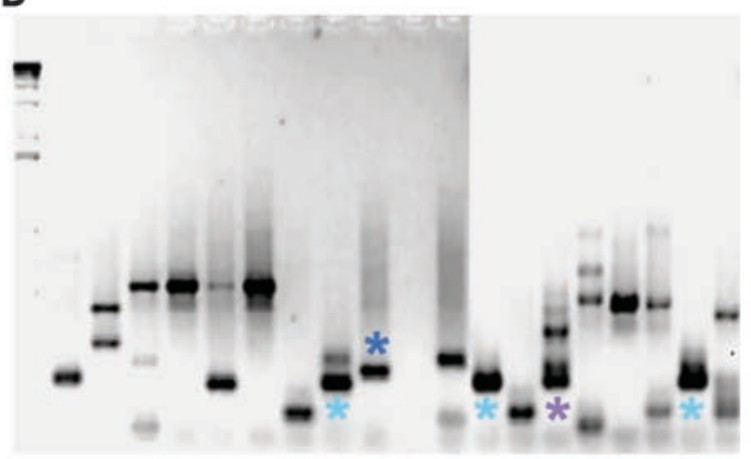

c

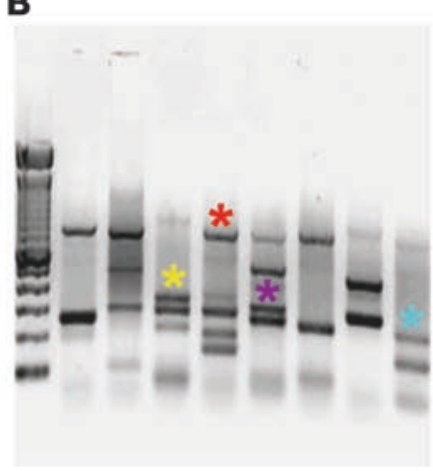

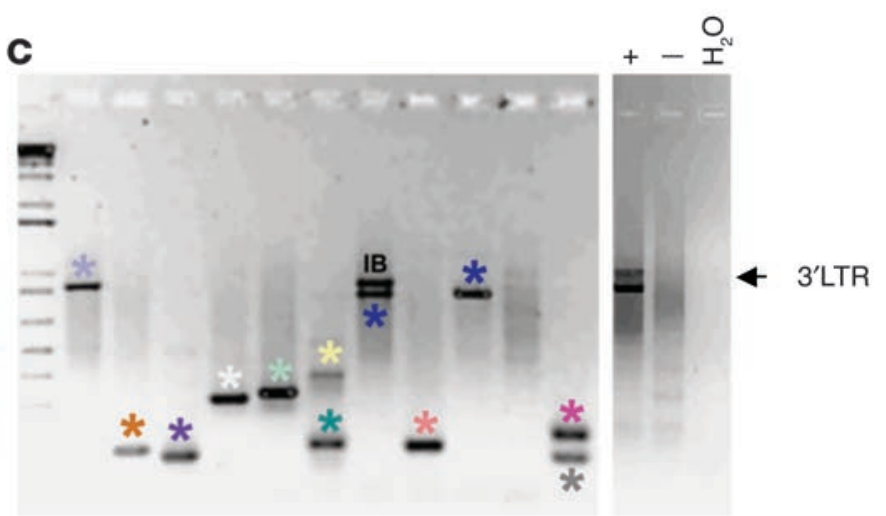

E

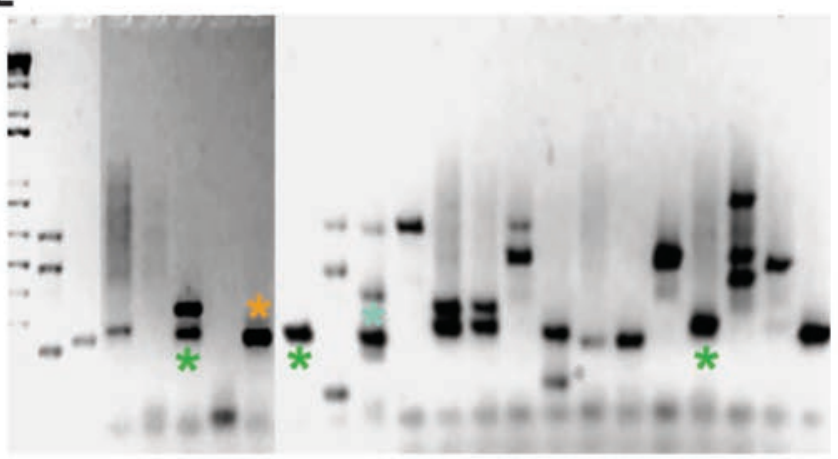

Figure 4

Bubble LM-PCR analysis of the number and dynamics of $\beta^{A-T 87 Q}$-globin lentivirus-positive clones in mice transplanted with transduced cord blood cells. (A-C) Analysis of individual CFC-derived colonies from 3 recipients (A, 1 recipient from experiment 4 analyzed 24 weeks after transplant; B and C, 2 mice from experiment 2, described in Figure 2A, analyzed 19 weeks after transplant). DNA from a transgene-negative colony was used as a negative control for the PCR, and DNA from a mouse spleen colony with a single integration confirmed by Southern blotting was used as a positive control. Note that the expected 750-bp 3' LTR-related fragment (IB) could not be detected in all of the colonies. The presence of identical faint bands in the analyses of several colonies is probably caused by cross contamination that occurred while plucking these colonies from the methylcellulose cultures. (D and E) Analysis of CFC-derived colonies from a third mouse from experiment 2 described in Figure $2 A$ analyzed 11 and 19 weeks after transplant. Bands with asterisks were gel purified and sequenced. Asterisks with the same color indicate colonies that showed the same integration site upon sequencing.

\section{Discussion}

Historically, the development of gene therapy approaches to SCD and $\beta$-thalassemia has been plagued by problems inherent in the design of stable vectors encoding human $\beta$-globin cassettes sufficient to direct the permanently very high levels of expression needed for the correction of these diseases. More recently, the risks of insertional mutagenesis have highlighted the need to achieve these goals with minimal copies of proviral integrants per cell (44). Here, we present the first evidence that a recently described selfinactivating lentiviral vector can be used to efficiently engineer the sustained production of anticipated therapeutic levels of an anti-sickling $\beta^{\mathrm{A}-\mathrm{T} 87 \mathrm{Q}-g l o b i n}$ protein in the erythroid progeny of pri- $^{-}$ mary human hematopoietic cells with in vivo-repopulating ability. We focused on normal cord blood as a target population for these initial studies because of the high frequency of NOD/SCID mouse-repopulating cells in cord blood $(45,46)$ and their reported ease of transduction after brief in vitro exposure to virus $(25,28$, $29,32,47-49)$. The demonstrated levels of anti-sickling $\beta^{\mathrm{A}-\mathrm{T} 87 \mathrm{Q}}$-globin protein in these cells constitute a significant advance and now underscore the need to extend these studies to adult HSCs.

Many groups have now shown that human HSCs with NOD/ SCID mouse-repopulating activity can be efficiently transduced after very brief exposure to lentiviral vectors in vitro without affecting their subsequent hematopoietic potential or ability to express the acquired transgene $(25,31,32,48,50-52)$. However, most of these findings have been limited to vectors carrying a ubiquitously expressed reporter or drug resistance gene. It remained to be demonstrated that such models could be extended effectively to vectors encoding a therapeutic gene and any additional sequences required for regulating their level and cell-specific expression. The findings presented here are the first to document this achievement with a vector carrying a $\beta$-globin gene. At least $20 \%$ of the CFCs regenerated in mice that had been repopulated with multiple clones of human cord blood cells exposed to concentrated preparations of this virus $\left(0.5 \times 10^{9}\right.$ to $1 \times 10^{9}$ infectious units $\left./ \mathrm{ml}\right)$ had the vector transgene, and values of more than $50 \%$ were noted in several mice. These findings indicate that the $\beta^{\mathrm{A}-\mathrm{T} 87 \mathrm{Q}}$-globin lentivirus can be used to transduce human cord blood cells with long-term NOD/ SCID mouse-repopulating activity with the same efficiency as has been reported for simpler constructs $(25,27,28,31,32,48,53)$.

Because we had found that prior overnight exposure to growth factors can increase the proportion of NOD/SCID mouse-repopulating cells that are ultimately transduced (data not shown), we adopted this approach. No perturbation of the normal pattern 


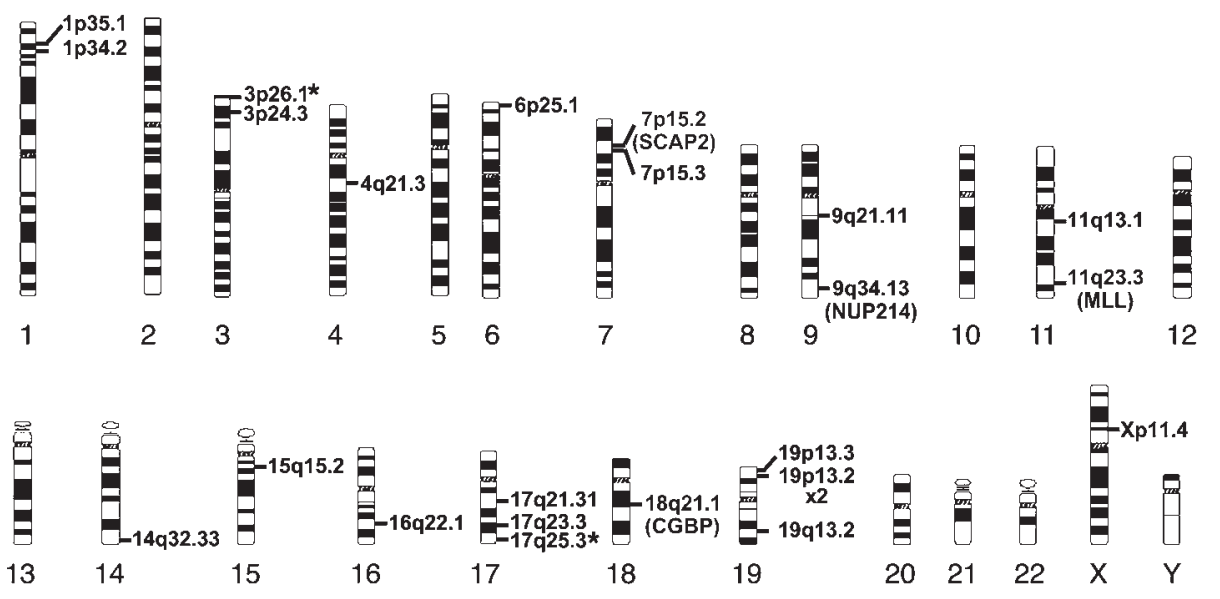

Figure 5

Chromosomal distribution of the sites of $\beta^{A-T 87 Q-g l o b i n ~ l e n t i v i r a l ~ v e c t o r ~ i n t e g r a t i o n . ~}$ Asterisks indicate sites of integration within predicted genes. of differentiation was observed in mice repopulated with the transduced cells. Also, multiple-lineage hematopoiesis was stable for as long as 4-6 months after transplant in the NOD/SCID hosts and for at least 13 months after transplant in the one NOD/SCID$n u / n u$ mouse that could be followed. Taken together, these findings indicate that the transduction protocol used had no significant or consistent biological effect on cord blood HSCs.

We did not attempt to document any changes in NOD/SCID mouse-repopulating cell activity that may have been incurred by the use of an overnight infection protocol, nor did we try to determine how these might have affected an ultimate net gain or loss in the absolute yield of transduced HSCs $(32,54)$. Clearly such data would be important to design a clinical protocol. The latter would also require re-examination of the timing and growth factor treatment needed to optimize the transduction of NOD/SCID mouse-repopulating cells in adult sources of human HSCs, since these are present at much lower frequencies than in cord blood $(45,55)$. Adult sources of HSCs are also known to be qualitatively as well as quantitatively different from cord blood HSCs in terms of the rate at which they can be activated into $G_{1}$ and the rate at which HSC function may be lost in vitro $(16,42,56-59)$.

We took advantage of the high gene transfer to human HSCs obtained in many experiments and the resultant high degree of repopulation of some mice with transduced human cells to investigate the clonal dynamics of this process. To identify different clones by the detection of unique proviral integration events, we analyzed hematopoietic colonies produced in vitro from in vivo-regenerated progenitors using a bubble LM-PCR method. Bubble LM-PCR was chosen because it is simpler to implement than other methods for detecting proviral inserts in small numbers of cells (fewer than $10^{3}$ ). Howev-
Table 2

Identity of intragenic $\beta^{\mathrm{A}-\mathrm{T} 870}$-globin lentiviral transgene integration sites

$\begin{array}{lccc}\text { Accession no. } & \text { Chromosomal band } & \text { Ref Seq gene name } & \text { Biological process } \\ \text { NM_144621 } & 1 \mathrm{p} 35.1 & \text { BOZF1 } & \text { Unknown } \\ \text { NM_006367 } & 1 \mathrm{p} 34.2 & \text { CAP1 } & \text { Signal transduction } \\ \text { NT_022517.90 } & 3 \mathrm{p} 26.1 & \text { Predicted gene } & - \\ \text { NM-014744 } & \text { 3p24.3 } & \text { TBC1D5 } & \text { Signal transduction } \\ \text { BC017432 } & 4 \mathrm{q} 21.3 & \text { MLLT2 } & \text { Cell growth and maintenance } \\ \text { AF285118 } & 6 \mathrm{p} 25.1 & \text { CGI-203 like gene } & \text { Unknown } \\ \text { NM_003930 } & 7 \mathrm{p} 15.2 & \text { SCAP2 } & \text { Signal transduction and } \\ & & & \text { metabolism } \\ \text { NM_018846 } & 7 \mathrm{p} 15.3 & \text { SBBI26 } & \text { Unknown } \\ \text { NM_001163 } & 9 \mathrm{q} 21.11 & \text { APBA1 } & \text { Development and cell adhesion } \\ & & & \text { and metabolism } \\ \text { NM_005085 } & 9 \mathrm{q} 34.13 & \text { NUP214 } & \text { Cell growth and maintenance } \\ \text { NM_006795 } & 11 \mathrm{q} 13.1 & \text { EHD1 } & \text { Unknown } \\ \text { NM_005933/ } & 11 \mathrm{q} 23.3 & \text { MLL and DDX6A } & \text { Transcription and cell growth } \\ \text { NM_004397 } & & & \text { and maintenance } \\ \text { NG_001019 } & 14 \mathrm{q} 32.33 & \text { IGHG3 } & \text { Immune response } \\ \text { NM_174916 } & 15 \mathrm{q} 15.2 & \text { UBR1 } & \text { Metabolism } \\ \text { NM_182619 } & 16 \mathrm{q} 22.1 & \text { LOC348174 } & \text { Unknown } \\ \text { NM_001002909 } & 17 \mathrm{q} 21.31 & \text { KIAA0553 } & \text { Unknown } \\ \text { NM_001433 } & 17 \mathrm{q} 23.3 & \text { ERN1 } & \text { Metabolism } \\ \text { NT_024871.61 } & 17 \mathrm{q} 25.3 & \text { Predicted gene } & \text { Transcription } \\ \text { NM_014593 } & 18 \mathrm{q} 21.1 & \text { CGBP } & \text { Signal transduction } \\ \text { NM_052847 } & 19 \mathrm{p} 13.3 & \text { GNG7 } & \text { Unknown } \\ \text { NM_080665 } & 19 \mathrm{p} 13.2 \mathrm{~B} & \text { MGC19604 } & \text { Transcription } \\ \text { NM_153358 } & 19 \mathrm{p} 13.2^{\mathrm{B}} & \text { FLJ90396 } & \text { Cell motility } \\ \text { NM_003370 } & 19 \mathrm{q} 13.2-q 13.3 & \text { VASP } & \text { Metabolism } \\ \text { NM_003688 } & \text { Xp11.4 } & \text { CASK } & \end{array}$

AThe integration is in the second intron of the DDX6 gene, which is located in the fifth intron of the $M L L$ gene. ${ }^{B}$ Genomic locus hit twice in two independent experiments. 
The present studies are also important in their demonstration of the high lineage-specific levels of $\beta^{\mathrm{A}-\mathrm{T} 87 \mathrm{Q}}$-globin produced in the erythroblast progeny of transduced HSCs. In many examples, these levels were above the estimated values of $20 \%$ of total $\beta$-globin per erythroid cell required to achieve a therapeutic effect in SCD and $\beta$-thalassemia $(41,61)$, even when all the $\beta$-like globin chains present in the cells were taken into consideration. Although the transgene copy number was estimated as 2 copies per cell, no meaningful calculation of the amount of $\beta^{\mathrm{A}-\mathrm{T} 87 \mathrm{Q}}$-globin protein produced per transgene copy was possible because the extracts analyzed were obtained from a highly heterogeneous mixture of erythroblasts at different stages of differentiation. Nevertheless, it is clear that the results obtained here represent a significant improvement over the levels of $\beta$-globin transgene-derived transcripts and protein recently documented in erythroblasts derived from human cord blood cells transduced with an oncoretroviral vector containing a similar $\beta$-globin cassette with a smaller LCR fragment (16).

We found that the majority $(24 / 28,86 \%)$ of the proviral integrations occurred within genes identified in RefSeq, and these included a number of genes that possess cell signaling or regulatory functions or that have been associated with leukemia. This proportion is significantly higher than would be expected $(P<0.0001)$ from the current estimates that genes occupy approximately $35 \%$ of the genome $(62,63)$. Thus our findings support the concept of preferred intragenic integration of lentiviral vectors into human DNA, as noted by others who reported $67 \%$ and $58 \%$ intragenic HIV-1 integrations in human lymphoid (64) and HeLa cells (65), respectively. We also observed preferential integration into introns $(21 / 24=88 \%$ of inserts characterized), as reported by others (64), perhaps reflecting the greater relative size of introns as compared with exons $(62,63)$. Taken together, these findings refocus attention on the possibility that such integration could result in activation or ablation of the expression of endogenous genes following the transduction of human HSCs, with functional consequences. As such, they point to the need for improvements in vector design aimed at both insulating integration sites from the effects of the provirus and minimizing the integrated proviral copy number required for therapeutic levels of expression.

\section{Methods}

Lentiviral vector design and production. The $\beta^{\mathrm{A}-\mathrm{T} 87 \mathrm{Q}}$-globin lentiviral vector used (Figure 1) was based on a vector previously described in detail (37) that was then modified to include the following additional safety features: a 400-bp deletion in U3 plus replacement of U5 in the right LTR with the polyadenylation/termination sequence of the rabbit $\beta$-globin gene and mutation of two potential ATG initiation codons in the $3^{\prime}$ portion of the packaging signal (details available upon request). High-titer recombinant virus pseudotyped with vesicular stomatitis virus glycoprotein-G was initially produced by using a standard 4-plasmid packaging system and later by using a recently developed "super-split" 7-plasmid packaging system (66). Recombinant virus made using the safety-modified vector and supersplit 7-plasmid packaging system was used in the last two experiments (one of which is experiment 2 presented in Figure 2A), whereas in the first three experiments (including experiment 1 in Figure 2A), the original vector (37) was used. Harvested virus-containing supernatants were concentrated by two rounds of ultracentrifugation approximately 1,000- to 2,000-fold to achieve titers of $0.5 \times 10^{9}$ to $1 \times 10^{9}$ infectious units $/ \mathrm{ml}$. Viral titers were determined using quantitative Southern blot analysis to compare vector DNA levels in cells containing a known number of integrated proviral copies with those in NIH $3 \mathrm{~T} 3$ cells infected with test virus preparations.
Absence of replication-competent virus in the viral supernatants was verified by a mobilization assay analogous to an assay previously employed for oncoretroviral vectors (67).

Isolation and transduction of human cord blood cells. Cord blood was obtained from consenting mothers undergoing cesarean delivery of healthy, fullterm infants, and low-density (less than $1.077 \mathrm{~g} / \mathrm{ml}$ ) cells were isolated by centrifugation on Ficoll-Hypaque (Pfizer). CD $34^{+}$cell-enriched populations (65-98\% CD34+ cells) were obtained by one of the following methods: (a) removal of lineage marker-positive cells using a column $(n=2)$; (b) sorting by FACSVantage SE $(n=1$; BD); (c) positive (EasySep) selection using magnetic beads ( $n=1$; StemCell Technologies Inc.). In one experiment, $\mathrm{CD} 34^{+} \mathrm{CD} 38^{-}$cells were isolated by FACS as previously described (46). Cells were stimulated overnight for in vivo experiments and for 48 hours for in vitro experiments at densities less than or equal to $2 \times 10^{5}$ cells $/ \mathrm{ml}$ in Iscove's medium supplemented with $1 \% \mathrm{BSA}, 10 \mu \mathrm{g} / \mathrm{ml}$ bovine pancreatic insulin, and $200 \mu \mathrm{g} / \mathrm{ml}$ human transferrin (BIT; StemCell Technologies Inc.), $10^{-4} \mathrm{~mol} 2$-mercaptoethanol, $2 \mathrm{mM}$ glutamine, $100 \mathrm{ng} / \mathrm{ml}$ FL (Immunex Corp.), $100 \mathrm{ng} / \mathrm{ml} \mathrm{SF}, 50 \mathrm{ng} / \mathrm{ml}$ Tpo (Genentech Inc.), and $100 \mathrm{ng} / \mathrm{ml} \mathrm{hIL-6}$ (provided by S. Rose-John, Christian-Albrechts University, Kiel, Germany). The following day, the cells were pelleted, resuspended in fresh growth factor-supplemented medium with $5 \mu \mathrm{g} / \mathrm{ml}$ protamine sulfate and $0.5 \times 10^{8}$ to $5 \times 10^{8}$ infectious units $/ \mathrm{ml}$ (MOI $=9-140 ; 140$ in experiment 1, 9 and 90 in experiment 2), placed in a 24-well plate coated with $2 \mu \mathrm{g} / \mathrm{cm}^{2}$ Retronectin (Takara Shuzo Co.) or with $5 \mu \mathrm{g} / \mathrm{cm}^{2}$ fibronectin (Sigma-Aldrich), and then incubated at $37^{\circ} \mathrm{C}$ for 6 hours. In experiment 2 , cells were plated in a Retronectin-coated well, which was then preloaded with virus for 2 hours at $4^{\circ} \mathrm{C}$.

In vitro CFC assays. Appropriate aliquots of human cells were plated in $1 \mathrm{ml}$ of methylcellulose-containing medium (Methocult H4230; StemCell Technologies Inc.) supplemented with $50 \mathrm{ng} / \mathrm{ml}$ human SF (purified from human SF cDNA-transfected Cos cell supernatants) and 20 $\mathrm{ng} / \mathrm{ml}$ each of human IL-3 (Novartis), IL-6 (Cangene), GM-CSF (Novartis), granulocyte-CSF (G-CSF; Novartis), and $3 \mathrm{U} / \mathrm{ml}$ erythropoietin (Epo; StemCell Technologies Inc.) (68). The cultures were then incubated for 2 weeks at $37^{\circ} \mathrm{C}$, and colonies of terminally differentiating erythroid, myeloid, and mixed erythroid-myeloid cells (from BFU-E, GM-CFU, and granulocyte-erythroid-megakaryocyte-macrophage-CFU [GEMM-CFU], respectively) were identified.

Animals. NOD/SCID mice and NOD/SCID- $n u / n u$ mice were bred and maintained in microisolators at our center. Original breeding pairs of NOD/ SCID-nu/nu mice were provided by J. Nolta (University of Washington, St. Louis, Missouri, USA), who obtained these mice by serially backcrossing the nude gene onto the NOD/SCID background for seven generations to give a host that supports human hematopoiesis in a fashion that is similar to the NOD/SCID mouse but without the development of endogenous thymomas and the resultant reduced lifespan of the NOD/SCID mouse (69).

At 8-10 weeks of age, mice were irradiated with $350 \mathrm{cGy}$ of ${ }^{137} \mathrm{Cs} \gamma$-rays the day prior to being intravenously injected with virus-infected human cells. (These cells were the progeny of an initial aliquot containing $1.7 \times 10^{5}$ to $4 \times 10^{5} \mathrm{CD}^{4} 4^{+}$or $7 \times 10^{4} \mathrm{CD} 34^{+} \mathrm{CD} 38^{-}$cord blood cells per mouse.) Thereafter, mice were given acidified water containing ciprofloxacin $(100 \mathrm{mg} / \mathrm{l}$; Bayer AG). Marrow cells were aspirated (70) 3, 7, 11, and 16 weeks after transplantation; the mice were killed 4-8 weeks later, and all cells from both tibiae and femurs were harvested for analysis. For phenotyping studies, cells were stained with human-specific monoclonal antibodies for total hematopoietic cells (CD45 and CD71), progenitors (CD34), B-lymphoid cells (CD19 and CD20), and granulopoietic cells (CD15), as previously described (71). Human multiple-lineage engraftment was defined as the detection of five or more $\mathrm{CD} 19 / 20^{+} \mathrm{CD} 34^{-}$and five or more CD15 ${ }^{+}$events per $2 \times 10^{4}$ live (propidium iodide-negative) events analyzed. In some instances, human $\mathrm{CD} 45 / 71^{+}$cells 
were isolated using a 3-laser FACSVantage SE (BD), as previously described (46), and then plated in methylcellulose cultures to generate hematopoietic colonies or placed in erythroid differentiation cultures.

PCR analysis. Cell lysates were prepared by incubating the cells from individually plucked colonies at $42^{\circ} \mathrm{C}$ for 30 minutes in the presence of proteinase $\mathrm{K}(1 \mathrm{mg} / \mathrm{ml})$. PCR was performed on $2 \mu \mathrm{l}(1 / 25 \mathrm{th})$ of these lysates using primers specific for human GAPDH (5'-ACCGTCAAGG CTGAGAAACGG- $3^{\prime}$ and $3^{\prime}$-ACGTACTCAGCGCCAGCATC- $\left.5^{\prime}\right)$ and for the $\beta^{\text {A-T87Q- }}$ globin transgene ( $5^{\prime}$-GGGCACCTTTGCCCAG-3' and $3^{\prime}$-TGGTCACGTCCGACGGATA-5') to amplify the expected 100 -bp and 600-bp fragments, respectively. After 40 cycles of denaturation $\left(30\right.$ seconds at $\left.94^{\circ} \mathrm{C}\right)$, annealing (30 seconds at $63.5^{\circ} \mathrm{C}$ ), and extension $\left(60\right.$ seconds at $72^{\circ} \mathrm{C}$ ), PCR products were separated on a $1.5 \%$ Tris-acetate EDTA (TAE) agarose gel.

RT-PCR analysis. Total RNA was extracted using a commercial kit (Trizol; Gibco BRL, Invitrogen Corp.) and reverse transcribed by random priming using $1 \mu \mathrm{g}$ of total RNA and SuperScript II Reverse Transcriptase (Invitrogen Corp.) at $42^{\circ} \mathrm{C}$ for 30 minutes, followed by denaturation at $72^{\circ} \mathrm{C}$ for 10 minutes and snap cooling to $4^{\circ} \mathrm{C}$ for 5 minutes. A PCR was then performed on undiluted and diluted $(1 / 2-1 / 4-1 / 8-1 / 16-1 / 32-1 / 64)$ cDNA using the same primer sets as those used for PCR to amplify the

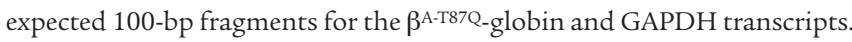
After 40 cycles of denaturation ( 30 seconds at $94^{\circ} \mathrm{C}$ ), annealing ( $30 \mathrm{sec}-$ onds at $\left.63.5^{\circ} \mathrm{C}\right)$, and extension $\left(60\right.$ seconds at $\left.72^{\circ} \mathrm{C}\right)$, the PCR products were separated on a $1.5 \%$ TAE agarose gel.

Erythroid differentiation cultures and analysis of globin protein. Cells were cultured for the first 9 days in $\alpha$-medium plus $15 \%$ FCS plus $1 \mathrm{U} / \mathrm{ml}$ Epo, 100 $\mathrm{ng} / \mathrm{ml} \mathrm{SF}, 40 \mathrm{ng} / \mathrm{ml} \mathrm{IGF-1} \mathrm{(R} \mathrm{\&} \mathrm{D} \mathrm{Systems),} 10^{-6} \mathrm{~mol}$ freshly dissolved hydrocortisone (Sigma-Aldrich), $10^{-6} \mathrm{~mol} 17 \beta$-estradiol (Sigma-Aldrich), $1.28 \mu \mathrm{g} / \mathrm{ml}$ iron-saturated transferring (StemCell Technologies Inc.), and $10^{-4} \mathrm{~mol} 2$-mercaptoethanol. The cells were then transferred to fresh $\alpha$-medium plus 15\% FCS, $1 \mathrm{U} / \mathrm{ml}$ Epo, $1 \mu \mathrm{g} / \mathrm{ml}$ insulin (Sigma-Aldrich), $1.28 \mu \mathrm{g} / \mathrm{ml}$ iron-saturated transferrin, and $10^{-4} \mathrm{~mol} 2$-mercaptoethanol for another 3-5 days; finally, cells were harvested and lysed using acid-acetone. Globins were analyzed by HPLC using a Vydac large-pore ( $300 \AA$ Å) $\mathrm{C}_{4}$ column and a modified acetonitrile $/ \mathrm{H}_{2} \mathrm{O} /$ trifluoroacetic acid gradient as previously

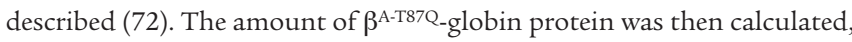
both as a percentage of the total $\beta$-globin present ( $\beta^{\mathrm{A}-\mathrm{T} 87 \mathrm{Q}}$-globin $/ \beta^{\mathrm{A}-\mathrm{T} 87 \mathrm{Q}}$ globin $+\beta^{A}$-globin $\times 100 \%$ ) and as a percentage of all $\beta$-like proteins present $\left(\beta^{\mathrm{A}-\mathrm{T} 87 \mathrm{Q}}\right.$-globin $/ \beta^{\mathrm{A}-\mathrm{T} 87 \mathrm{Q}}$-globin $+\beta^{\mathrm{A}}$-globin $+\gamma^{\mathrm{G}}$-globin $+\gamma^{\mathrm{A}}$-globin $\left.\times 100 \%\right)$.

$L M-P C R$. Integrated LTR and flanking genomic sequences were amplified and then isolated using a modification of the bubble LM-PCR strategy (73). Aliquots of the cell lysates from transgene-positive colonies (5-10 $\mu \mathrm{l}$; one-fifth to one-tenth) were digested with Hinfl (New England Biolabs), and the fragments were then ligated overnight at room temperature to a doublestranded bubble linker (5'-CTCTCCCTTCTCGAA TCGTAACCGTTCGTACGAGAATCGCTGTCCTCTCCTTG- ${ }^{\prime}$ and $5^{\prime}$-ANTCAAGGAGAGGACGCTGTCTGTCGAAGGTAAGGAACGGACGAGAGAAGGGA GAG-3') prior to performing a first PCR (PCR-A) on $10 \mu \mathrm{l}$ (one-tenth) of the ligation product using a linker-specific Vectorette primer (5'-CGAATCGTAACCGTTCGTACGAGAATCGCT-3') and an LTR-specific primer (LTR-A: 5'CAACACACACATTGAAGCACTCAAGGCAAG- $3^{\prime}$ ) and under the following conditions: one cycle of $94^{\circ} \mathrm{C}$ for 2 minutes, 20 cycles of $94^{\circ} \mathrm{C}$ for 30 seconds and $65^{\circ} \mathrm{C}$ for 1 minute, and one cycle of $72^{\circ} \mathrm{C}$ for 2 minutes. The bubble linker contains a 30-nucleotide nonhomologous sequence in the middle region that prevents binding of the linker primer in the absence of minus strand generated by the LTR-specific primer. A 1- $\mu$ l aliquot of the PCR-A reaction (one-fifteenth) was then used as a template for a second nested PCR (PCR-B) using an internal LTR-specific primer (LTR-B: 5'-GAGAGCTCCCAG GCTCAGATCTGGTCTAAC-3') and the same linker-specific Vectorette primer as was used in PCR-A with the following conditions: one cycle of $94^{\circ} \mathrm{C}$ for 2 minutes, 30 cycles of $94^{\circ} \mathrm{C}$ for 60 seconds and $72^{\circ} \mathrm{C}$ for 1 minute, and one cycle of $72^{\circ} \mathrm{C}$ for 2 minutes. Ten microliters (one-half) of the final PCR-B product were electrophoresed using $2 \%$ agarose TAE gel. Individual bands were excised and purified using the Qiaex II Gel Extraction Kit (QIAGEN) for sequencing. Two types of marked fragments were obtained. One was always $750 \mathrm{bp}$, representing the vector sequence bound by the primer specific to the $3^{\prime}$ LTR and the next Hinfl restriction site. The other was of variable length (158 bp or more) depending on the distance to the next Hinfl site in the host genome adjacent to the $5^{\prime}$ LTR.

Sequence analysis. Gel-purified DNA bands were sequenced directly from the LTR-B primer with the ABI PRISM Model 377 according to the manufacturer's instructions. Only sequences containing both complete 5' LTR and intact Hinfl-linked Vectorette ends were analyzed. Sequencing of fragments with identical lengths sometimes yielded different integration sites. The sensitivity of determining the number of proviral integrations per colony could be increased by further cloning of the gel-isolated fragments. BLAST searches were performed using the University of California Santa Cruz (UCSC) genome project website (http://genome.ucsc.edu) to identify the genomic location of the flanking sequences. Chromosomal localizations of the mapped genes were determined using the Ensembl map viewer (http://www.ensembl.org).

\section{Acknowledgments}

This work was supported by grants from the NIH (Program Project grant HL 55435 to C.J. Eaves, M.E. Fabry, R.K. Humphries, P. Leboulch, and R.L. Nagel; HL38055 and HL68962 to R.L. Nagel), the Stem Cell Network (to C.J. Eaves and R.K. Humphries), and the International Cooley's Anemia Foundation (to R.L. Nagel). P. Tang received a Research Studentship from the Stem Cell Network. The authors thank Lars Palmquist for integration site analysis; Sandy Suzuka, members of the Stem Cell Assay Service of the Terry Fox Laboratory, Sanja Sekulovic, Margaret Hale, and Michael Schertzer for technical help; StemCell Technologies Inc., Immunex Corporation, Genentech, P. Lansdorp, and S. Rose-John for gifts of reagents; and Colleen MacKinnon for assistance in manuscript preparation.

Received for publication April 9, 2004, and accepted in revised form July 20, 2004.

Address correspondence to: R. Keith Humphries, Terry Fox Laboratory, 601 West 10th Avenue, Vancouver, British Columbia V5Z 1L3, Canada. Phone: (604) 877-6070, ext. 3095; Fax: (604) 877-0712; E-mail: khumphri@bccrc.ca.

Connie J. Eaves and R. Keith Humphries contributed equally to this work.
1. Olivieri, N.F. 1999. The beta-thalassemias. N. Engl. J. Med. 341:99-109.

2. Walters, M.C., et al. 1996. Barriers to bone marrow transplantation for sickle cell anemia. Biol. Blood Marrow Transplant. 2:100-104.

3. Tuan, D., and London, I.M. 1984. Mapping of DNase I-hypersensitive sites in the upstream DNA of human embryonic epsilon-globin gene in K562 leukemia cells. Proc. Natl. Acad. Sci. U. S. A. 81:2718-2722.

4. Tuan, D., Solomon, W., Li, Q., and London, I.M. 1985. The "beta-like-globin" gene domain in human erythroid cells. Proc. Natl. Acad. Sci. U. S. A. 82:6384-6388.

5. Wright, S., Rosenthal, A., Flavell, R., and Grosveld, F. 1984. DNA sequences required for regulated expression of beta-globin genes in murine erythro- leukemia cells. Cell. 38:265-273.

6. Forrester, W.C., Takegawa, S., Papayannopoulou, T., Stamatoyannopoulos, G., and Groudine, M. 1987. Evidence for a locus activation region: the formation of developmentally stable hypersensitive sites in globin-expressing hybrids. Nucleic Acids Res. 15:10159-10177.

7. Grosveld, F., et al. 1987. The regulation of expres- 
sion of human beta-globin genes. Prog. Clin. Biol. Res. 251:133-144.

8. Blom van Assendelft, G., Hanscombe, O., Grosveld, F., and Greaves, D.R. 1989. The beta-globin dominant control region activates homologous and heterologous promoters in a tissue-specific manner. Cell. 56:969-977.

9. Talbot, D., et al. 1989. A dominant control region from the human beta-globin locus conferring integration site-independent gene expression. Nature. 338:352-355.

10. Fraser, P., Hurst, J., Collis, P., and Grosveld, F. 1990. DNaseI hypersensitive sites 1, 2 and 3 of the human beta-globin dominant control region direct position-independent expression. Nucleic Acids Res. 18:3503-3508.

11. Leboulch, P., et al. 1994. Mutagenesis of retroviral vectors transducing human beta-globin gene and beta-globin locus control region derivatives results in stable transmission of an active transcriptional structure. EMBO J. 13:3065-3076.

12. Sadelain, M., Wang, C.H., Antoniou, M., Grosveld, F., and Mulligan, R.C. 1995. Generation of a hightiter retroviral vector capable of expressing high levels of the human beta-globin gene. Proc. Natl. Acad. Sci.U. S. A. 92:6728-6732.

13. Raftopoulos, H., Ward, M., Leboulch, P., and Bank, A. 1997. Long-term transfer and expression of the human beta-globin gene in a mouse transplant model. Blood. 90:3414-3422.

14. Kalberer, C.P., et al. 2000. Preselection of retrovirally transduced bone marrow avoids subsequent stem cell gene silencing and age-dependent extinction of expression of human beta-globin in engrafted mice. Proc. Natl. Acad. Sci. U. S. A. 97:5411-5415.

15. Nicolini, F.E., et al. 2002. Expression of a human beta-globin transgene in erythroid cells derived from retrovirally transduced transplantable human fetal liver and cord blood cells. Blood. 100:1257-1264.

16. Oh, I.H., et al. 2004. Expression of an anti-sickling beta-globin in human erythroblasts derived from retrovirally transduced primitive normal and sickle cell disease hematopoietic cells. Exp. Hematol. 32:461-469.

17. Dzierzak, E.A., Papayannopoulou, T., and Mulligan, R.C. 1988. Lineage-specific expression of a human beta-globin gene in murine bone marrow transplant recipients reconstituted with retrovirustransduced stem cells. Nature. 331:35-41.

18. Bender, M.A., Gelinas, R.E., and Miller, A.D. 1989. A majority of mice show long-term expression of a human beta-globin gene after retrovirus transfer into hematopoietic stem cells. Mol. Cell. Biol. 9:1426-1434.

19. Plavec, I., Papayannopoulou, T., Maury, C., and Meyer, F. 1993. A human beta-globin gene fused to the human beta-globin locus control region is expressed at high levels in erythroid cells of mice engrafted with retrovirus-transduced hematopoietic stem cells. Blood. 81:1384-1392.

20. Rivella, S., and Sadelain, M. 1998. Genetic treatment of severe hemoglobinopathies: the combat against transgene variegation and transgene silencing. Semin. Hematol. 35:112-125.

21. Rebel, V.I., et al. 1999. One-day ex vivo culture allows effective gene transfer into human nonobese diabetic/severe combined immune-deficient repopulating cells using high-titer vesicular stomatitis virus $\mathrm{G}$ protein pseudotyped retrovirus. Blood. 93:2217-2224.

22. Hennemann, B., et al. 2000. Efficient retrovirusmediated gene transfer to transplantable human bone marrow cells in the absence of fibronectin. Blood. 96:2432-2439.

23. Dorrell, C., Gan, O.I., Pereira, D.S., Hawley, R.G., and Dick, J.E. 2000. Expansion of human cord blood CD34(+)CD38(-) cells in ex vivo culture during retroviral transduction without a cor- responding increase in SCID repopulating cell (SRC) frequency: dissociation of SRC phenotype and function. Blood. 95:102-110.

24. Uchida, N., et al. 1998. HIV, but not murine leukemia virus, vectors mediate high efficiency gene transfer into freshly isolated G0/G1 human hematopoietic stem cells. Proc. Natl. Acad. Sci. U. S. A. 95:11939-11944.

25. Miyoshi, H., Smith, K.A., Mosier, D.E., Verma, I.M., and Torbett, B.E. 1999. Transduction of human $\mathrm{CD} 34^{+}$cells that mediate long-term engraftment of NOD/SCID mice by HIV vectors. Science. 283:682-686.

26. Case, S.S., et al. 1999. Stable transduction of quiescent CD34(+)CD38(-) human hematopoietic cells by HIV-1-based lentiviral vectors. Proc. Natl. Acad. Sci. U. S. A. 96:2988-2993.

27. Follenzi, A., Ailles, L.E., Bakovic, S., Geuna, M., and Naldini, L. 2000. Gene transfer by lentiviral vectors is limited by nuclear translocation and rescued by HIV-1 pol sequences. Nat. Genet. 25:217-222.

28. Guenechea, G., et al. 2000. Transduction of human CD $34^{+} \mathrm{CD}^{-} 8^{-}$bone marrow and cord bloodderived SCID-repopulating cells with third-generation lentiviral vectors. Mol. Ther. 1:566-573.

29. Woods, N.B., et al. 2000. Lentiviral gene transfer into primary and secondary NOD/SCID repopulating cells. Blood. 96:3725-3733.

30. Scherr, M., et al. 2002. Lentiviral gene transfer into peripheral blood-derived CD $34^{+} \mathrm{NOD} / \mathrm{SCID}$ repopulating cells. Blood. 99:709-712.

31. Ailles, L., et al. 2002. Molecular evidence of lentiviral vector-mediated gene transfer into human self-renewing, multi-potent, long-term NOD/SCID repopulating hematopoietic cells. Mol. Ther. 6:615-626.

32. Mazurier, F., Gan, O.I., McKenzie, J.L., Doedens, M., and Dick, J.E. 2004. Lentivector-mediated clonal tracking reveals intrinsic heterogeneity in the human hematopoietic stem cell compartment and culture-induced stem cell impairment. Blood. 103:545-552.

33. Naldini, L., and Verma, I.M. 2000. Lentiviral vectors. Adv. Virus Res. 55:599-609.

34. Lois, C., Hong, E.J., Pease, S., Brown, E.J., and Baltimore, D. 2002. Germline transmission and tissue-specific expression of transgenes delivered by lentiviral vectors. Science. 295:868-872.

35. Pfeifer, A., and Verma, I.M. 2001. Gene therapy: promises and problems. Annu. Rev. Genomics Hum. Genet. 2:177-211.

36. May, C., et al. 2000. Therapeutic haemoglobin synthesis in beta-thalassaemic mice expressing lentivirus-encoded human beta-globin. Nature. 406:82-86.

37. Pawliuk, R., et al. 2001. Correction of sickle cell disease in transgenic mouse models by gene therapy. Science. 294:2368-2371.

38. Imren, S., et al. 2002. Permanent and panerythroid correction of murine beta thalassemia by multiple lentiviral integration in hematopoietic stem cells. Proc. Natl. Acad. Sci. U. S. A. 99:14380-14385.

39. May, C., Rivella, S., Chadburn, A., and Sadelain, M. 2002. Successful treatment of murine beta-thalassemia intermedia by transfer of the human betaglobin gene. Blood. 99:1902-1908.

40. Persons, D.A., Hargrove, P.W., Allay, E.R., Hanawa, H., and Nienhuis, A.W. 2003. The degree of phenotypic correction of murine beta -thalassemia intermedia following lentiviral-mediated transfer of a human gamma-globin gene is influenced by chromosomal position effects and vector copy number. Blood. 101:2175-2183.

41. Levasseur, D.N., Ryan, T.M., Pawlik, K.M., and Townes, T.M. 2003. Correction of a mouse model of sickle cell disease: lentiviral/antisickling betaglobin gene transduction of unmobilized, purified hematopoietic stem cells. Blood. 102:4312-4319.
42. Holyoake, T.L., Nicolini, F.E., and Eaves, C.J. 1999. Functional differences between transplantable human hematopoietic stem cells from fetal liver, cord blood, and adult marrow. Exp. Hematol. 27:1418-1427.

43. Glimm, H., et al. 2001. Previously undetected human hematopoietic cell populations with short-term repopulating activity selectively engraft NOD/SCID-beta2 microglobulin-null mice. J. Clin. Invest. 107:199-206.

44. Hacein-Bey-Abina, S., et al. 2003. LMO2-associated clonal $\mathrm{T}$ cell proliferation in two patients after gene therapy for SCID-X1. Science. 302:415-419.

45. Wang, J.C., Doedens, M., and Dick, J.E. 1997. Primitive human hematopoietic cells are enriched in cord blood compared with adult bone marrow or mobilized peripheral blood as measured by the quantitative in vivo SCID-repopulating cell assay. Blood. 89:3919-3924.

46. Conneally, E., Cashman, J., Petzer, A., and Eaves, C. 1997. Expansion in vitro of transplantable human cord blood stem cells demonstrated using a quantitative assay of their lympho-myeloid repopulating activity in nonobese diabetic-scid/scid mice. Proc. Natl. Acad. Sci. U. S. A. 94:9836-9841.

47. Ailles, L.E., and Naldini, L. 2002. HIV-1-derived lentiviral vectors. Curr. Top. Microbiol. Immunol. 261:31-52.

48. Amsellem, S., Ravet, E., Fichelson, S., Pflumio, F., and Dubart-Kupperschmitt, A. 2002. Maximal lentivirus-mediated gene transfer and sustained transgene expression in human hematopoietic primitive cells and their progeny. Mol. Ther. 6:673-677.

49. Zielske, S.P., and Gerson, S.L. 2003. Cytokines, including stem cell factor alone, enhance lentiviral transduction in nondividing human LTCIC and NOD/SCID repopulating cells. Mol. Ther. 7:325-333.

50. Woods, N.B., Ooka, A., and Karlsson, S. 2002. Development of gene therapy for hematopoietic stem cells using lentiviral vectors. Lenkemia. 16:563-569.

51. Scherr, M., and Eder, M. 2002. Gene transfer into hematopoietic stem cells using lentiviral vectors. Curr. Gene Ther. 2:45-55.

52. Zielske, S.P., Reese, J.S., Lingas, K.T., Donze, J.R., and Gerson, S.L. 2003. In vivo selection of MGMT(P140K) lentivirus-transduced human NOD/SCID repopulating cells without pretransplant irradiation conditioning. J. Clin. Invest. 112:1561-1570. doi:10.1172/JCI200317922.

53. Piacibello, W., et al. 2002. Lentiviral gene transfer and ex vivo expansion of human primitive stem cells capable of primary, secondary, and tertiary multilineage repopulation in NOD/SCID mice. Nonobese diabetic/severe combined immunodeficient. Blood. 100:4391-4400.

54. Takatoku, M., et al. 2001. Avoidance of stimulation improves engraftment of cultured and retrovirally transduced hematopoietic cells in primates. J. Clin. Invest. 108:447-455. doi:10.1172/JCI200112593.

55. van der Loo, J.C., et al. 1998. Nonobese diabetic/ severe combined immunodeficiency (NOD/SCID) mouse as a model system to study the engraftment and mobilization of human peripheral blood stem cells. Blood. 92:2556-2570.

56. Hennemann, B., et al. 1999. Optimization of retroviral-mediated gene transfer to human NOD/SCID mouse repopulating cord blood cells through a systematic analysis of protocol variables. Exp. Hematol. 27:817-825.

57. Cashman, J.D., Clark-Lewis, I., Eaves, A.C., and Eaves, C.J. 1999. Differentiation stage-specific regulation of primitive human hematopoietic progenitor cycling by exogenous and endogenous inhibitors in an in vivo model. Blood. 94:3722-3729.

58. Glimm, H., Oh, I.H., and Eaves, C.J. 2000. Human hematopoietic stem cells stimulated to proliferate 
in vitro lose engraftment potential during their $\mathrm{S} / \mathrm{G}(2) / \mathrm{M}$ transit and do not reenter $\mathrm{G}(0)$. Blood. 96:4185-4193.

59. Oh, I.H., Lau, A., and Eaves, C.J. 2000. During ontogeny primitive (CD34(+)CD38(-)) hematopoietic cells show altered expression of a subset of genes associated with early cytokine and differentiation responses of their adult counterparts. Blood. 96:4160-4168.

60. Kuramoto, K., et al. 2004. The impact of chronic low-dose busulfan on clonal dynamics in nonhuman primates. Blood. 104:1273-1280.

61. Persons, D.A., et al. 2001. Functional requirements for phenotypic correction of murine beta-thalassemia: implications for human gene therapy. Blood. 97:3275-3282.

62. Lander, E.S., et al. 2001. Initial sequencing and analysis of the human genome. Nature. 409:860-921.

63. Venter, J.C., et al. 2001. The sequence of the human genome. Science. 291:1304-1351.
64. Schroder, A.R., et al. 2002. HIV-1 integration in the human genome favors active genes and local hotspots. Cell. 110:521-529.

65. Wu, X., Li, Y., Crise, B., and Burgess, S.M. 2003 Transcription start regions in the human genome are favored targets for MLV integration. Science. 300:1749-1751.

66. Westerman, K.A., Morales, T., Pawliuk, R., Cohen, E., and LeBoulch, P. 2003. A high titer, "supersplit" packaging system in combination with self-inactivating vector for the prevention of replication competent lentivirus (RCL) contamination [abstract]. Mol. Ther. 7:6A.

67. Pawliuk, R., Kay, R., Lansdorp, P., and Humphries, R.K. 1994. Selection of retrovirally transduced hematopoietic cells using CD24 as a marker of gene transfer. Blood. 84:2868-2877.

68. Sutherland, H.J., Eaves, C.J., Eaves, A.C., Dragowska, W., and Lansdorp, P.M. 1989. Characterization and partial purification of human marrow cells capable of initiating long-term hematopoiesis in vitro. Blood. 74:1563-1570.

69. Meyerrose, T.E., Herrbrich, P., Hess, D.A., and Nolta, J.A. 2003. Immune-deficient mouse models for analysis of human stem cells. Biotechniques. 35:1262-1272.

70. Verlinden, S.F., van Es, H.H., and van Bekkum, D.W. 1998. Serial bone marrow sampling for long-term follow up of human hematopoiesis in NOD/SCID mice. Exp. Hematol. 26:627-630.

71. Eaves, C., et al. 1997. Hematopoietic stem cells: inferences from in vivo assays. Stem Cells. 15(Suppl. 1):1-5.

72. Fabry, M.E., et al. 1995. A second generation transgenic mouse model expressing both hemoglobin S (HbS) and HbS-Antilles results in increased phenotypic severity. Blood. 86:2419-2428.

73. Riley, J., et al. 1990. A novel, rapid method for the isolation of terminal sequences from yeast artificial chromosome (YAC) clones. Nucleic Acids Res. 18:2887-2890. 